\title{
Review of Water Environment Trans-boundary Management in Songliao Basin
}

\author{
Zhang Zhaohan ${ }^{1,2^{*}, \mathrm{a}}$, Xiang Lijun ${ }^{2, \mathrm{~b}}$, Zheng Guochen ${ }^{3, \mathrm{~b}}$, Feng Yujie ${ }^{2, \mathrm{c}}$, Liu Wei ${ }^{1^{*}, \mathrm{~d}}$ \\ ${ }^{1}$ Heilongjiang River Fisheries Research Institute, Chinese Academy of Fishery Sciences, No 43, \\ Songfa Street, Daoli District, Harbin 150001, China \\ ${ }^{2}$ State Key Laboratory of Urban Water Resource and Environment, Harbin Institute of Technology, \\ No73, Huanghe Road, Nangang District, Harbin 150090, China \\ ${ }^{3}$ Songliao River Basin Water Resources Protection Bureau, Changchun 130021 \\ ahitzzh@sina.com, bhitzzh@hit.edu.cn, yujief@yahoo.com, ${ }^{d}$ zhanpr@yahoo.com.cn
}

Keywords: Songliao Basin; Water environment management; Trans-boundary management; Review

\begin{abstract}
Basin management is a kind of protection and management activity for water environment with watershed as the basic unit. The cross-border property of watershed promotes the formation of trans-boundary water environment management in a basin. Referring to some related experience abroad and combining with the management status of domestic watershed, the research achievements and existed problems of trans-boundary water environment management in Songliao Basin were analyzed in this paper, and some feasible suggestions were also proposed.
\end{abstract}

\section{Significance and purposes of trans-boundary management for basin water environment}

For implementing the decisions and arrangements of central committee on water conservancy reformation, Water ministry printed instruction to deepen reforms and put forward the tasks in 10 important areas, such as Water administrative functions, water resources management system, water system of ecological civilization, rivers management and protection system, etc. It also proposes high standards for trans-boundary management for basin water environment. Trans-boundary water problems include cross-provincial and cross-border. Due to the enormous difference on management and standard of both sides, international coordination for cross-border water problems became more complex and difficult. Though most of the cross-provincial rivers in China are managed according to the demand of Water ministry, many problems also exists in practical works, including: (1) Trans-boundary management was conducted by multiple agencies, (2) water pollution control must coordinate with flood control, and it makes the trans-boundary contradiction more complex, and (3) shortage of related law system and governance standards make the trans-boundary water management and pollution control becoming the main problems of environmental governance ${ }^{[1]}$. Therefore, it is significant to investigate the trans-boundary management for basin water environment.

\section{Experience and revelation of trans-boundary management for basin water environment in other countries}

Comparison of the basin trans-boundary management system. In most countries, basin management was hierarchical, and divided into national, basin and regional level ${ }^{[2]}$. In national level, management agencies focus on nationwide water management, and it included integrated and decentralized management. Integrated management implied water management function centralized in some special organization, while decentralized management meant that different agencies undertook different functions. In regional level, it took the states as the basic unit and management subject included state government, public utility departments and regional water management enterprise. In basin level, it was comprehensive managed. According to their function, the management agency was divided into three classes: water resources council for coordination, River 
basin Committees for planning and development, and valley authority for development and management ${ }^{[3]}$. The system, organization, laws and methods for water environment trans-boundary management of basin in China and other countries were compared, as shown in Table 1.

Table 1 Comparing the system, organization, laws and methods for water environment trans-boundary management of basin in China and other countries ${ }^{[4-6]}$

\begin{tabular}{|c|c|c|c|c|c|}
\hline & America & Japan & Australia & European Union & China \\
\hline $\begin{array}{l}\text { Management } \\
\text { system }\end{array}$ & $\begin{array}{c}\text { Integrated } \\
\text { management }\end{array}$ & $\begin{array}{l}\text { Decentralized } \\
\text { management }\end{array}$ & $\begin{array}{c}\text { Integrated } \\
\text { management }\end{array}$ & $\begin{array}{c}\text { Comprehensivemana } \\
\text { gement }\end{array}$ & $\begin{array}{c}\text { Basin+Regionalmmanagem } \\
\text { ent }\end{array}$ \\
\hline $\begin{array}{l}\text { Management } \\
\text { Organization }\end{array}$ & Valley Authority & No special agencies & $\begin{array}{l}\text { River basin } \\
\text { Committees, } \\
\text { Water council }\end{array}$ & $\begin{array}{c}\text { River basin } \\
\text { Committees, } \\
\text { European union }\end{array}$ & $\begin{array}{c}\text { River basin Committees, } \\
\text { Valley Authority }\end{array}$ \\
\hline $\begin{array}{l}\text { Management } \\
\text { laws }\end{array}$ & $\begin{array}{c}\text { Clean water act, Safe } \\
\text { drinking water act, } \\
\text { Planning law for water, } \\
\text { Valley management act, } \\
\text { Federal water } \\
\text { pollution control act, } \\
\text { etc. }\end{array}$ & $\begin{array}{c}\text { Promotion act for } \\
\text { water development, } \\
\text { Community law for } \\
\text { water development, } \\
\text { Rivers and Habors } \\
\text { Act, etc. }\end{array}$ & $\begin{array}{c}\text { Soil and water } \\
\text { conservation law, } \\
\text { Valley } \\
\text { management act, } \\
\text { Murray-Darling } \\
\text { Basin agreement }\end{array}$ & $\begin{array}{l}\text { Water Framework Di } \\
\text { rective, } \\
\text { protection protocol } \\
\text { for River Rhine }\end{array}$ & $\begin{array}{c}\text { Water Act, Constitution, } \\
\text { environmental protection } \\
\text { laws, Law on } \\
\text { the Prevention and Control } \\
\text { of Water Pollution, Flood } \\
\text { Control Law, etc }\end{array}$ \\
\hline $\begin{array}{l}\text { Related } \\
\text { management } \\
\text { methods }\end{array}$ & $\begin{array}{l}\text { Command and } \\
\text { control measures; } \\
\text { Economic means; } \\
\text { Responsibility } \\
\text { investigation; }\end{array}$ & $\begin{array}{l}\text { Command control; } \\
\text { Economic } \\
\text { incentives }\end{array}$ & TCM policy & $\begin{array}{l}\text { Water action in } \\
\text { European union, } \\
\text { Neighbor country } \\
\text { policy, } \\
\text { Helsinki Accords }\end{array}$ & $\begin{array}{c}\text { Environmental impact asse } \\
\text { ssment, } \\
\text { "Three simultaneous" syst } \\
\text { em, Pollution } \\
\text { discharge fee system, } \\
\text { Accountability }\end{array}$ \\
\hline
\end{tabular}

Experience of basin trans-boundary management in other countries. In America, Tennessee River Valley Authority gained many experiences on trans-boundary water environment management. Firstly, federal laws and policies supplied guarantees for trans-boundary basin management. Secondly, they established a special agency to manage the whole basin and do the development plans. Finally, powerful management system guaranteed the correct water environment trans-boundary management. In Japan, Shiga government adopted a series of comprehensive control measures to manage the Lake Biwa basin. They took the basin as the unit and respectively made the corresponding policies. For example, afforestation and closing hillsides in upper of basin were adopted to prevent soil erosion, dredging the channel in midstream was used to reduce pollution, and saving water was encouraged in the downstream water using area. In Australia, Murray-Darling basin adopted a series of policies and measurements to realize the equal, high efficiency and sustainable utilization of water environment resources, which included the formulation of Murray darling basin action and management strategy of water environment ${ }^{[7]}$.

The management experience of River Rhine included: (1) Water quality standard of River Rhine basin was scientifically formulated, and water quality was detailed classified management. (2) Environmental protection Laws were strictly enforced. Countries along the river all deployed plenty of manpower and financial resources to control the total pollution load and make the ecological environment of estuary keeping good. (3) Strengthening the infrastructure construction of Rhine basin and controlling the total amount of pollutant. (4) The monitoring sections were scientifically set along the river, and the advanced monitoring technologies and equipment were used to monitor the water quality changes. (5) The management agency formulated the long-term plan for the sustainable development of Rhine basin. All countries along the river coordinated to develop the economics and control the pollutant amount.

Revelation of basin trans-boundary management in other countries. Though the policies of total quantity control, pollution charges and emission rights trading have been widely used in trans-boundary water management, the contradiction between the imbalance of regional economic development and trans-boundary water pollution is very difficult to be solved. We can get some successful experience from abroad basin management, and the revelations include: (1) taking the law as the guarantee; (2) basin management agency having the executive force; (3) paying more attention on technology development and application; (4) designing multiple goals for basin development and management to maximize the benefits; (5) national supports on policies and funds; (6) scientific and 
reasonable plan for basin management; (7) encouraging the public participation; (8) formulating the suitable water quality standard according to the application purposes of water; (9) paying more attention on research of management theory and practice.

\section{Present situation of Trans-boundary water management in China}

Focusing on the trans-boundary water pollution area, China had established several management systems.

Joint conference system. This system supplied a communication and coordination platform for agencies and governments at all levels to discuss the environmental problems. Now, the State Council has established more than 40 joint conference systems. It can solve some problems between different departments and regions, with the advantage of concentrating more wisdom to conduct mutual supervision. The disadvantage included: dispersed responsibility, limited power and low efficiencies of implementation.

River basin commission system. Due to present basin agencies be affiliated with Ministry of Water Resources, the comprehensive and market adjusted management system were established to implement the general management of water resources and water pollution control. Basin commission can be composed by related departments, specialist, water users, pollution dischargers and public representatives. It can form the comprehensive management agency with basin functional organization in present law frame scope. The management of this type is much concentrated, and the responsibility is much clear. The management on water resources and water environment is more comprehensive and professional, and mainly focus on the sustainable development of environmental benefits, which had evident advantage for basin management. However, due to lack of the mandatory enforcement right, the restrain force on other departments is weak.

River basin administration system. From the point of solving the trans-boundary disputes, reformation of present basin management system mainly focus on establishing systematic and comprehensive management system to coordinate the water resources in different administrative regions. The evolution trend of international water resources management indicated that the management changing from region to basin, and decentralized to integrated pay more attention on the objectivity of basin system. The management system based on government levels structure was important to coordinate the contradiction of different department in each levels by reforming the agency, system and acts.

\section{Trans-boundary water management of Songliao basin}

Current situation analysis. The basic characteristics of trans-boundary management mode in Songliao basin include: (1) comprehensively considering the basin and region benefits; (2) jointing different regions to coordinate the relationship and improve the regional water environment; (3) jointing different industries to enhance advantage and avoid disadvantage; (4) cooperating of different departments to benefit the comprehensive control and joint law enforcement.

The water quality in buffer area between two provinces was kept in good condition, indicating that the water quality satisfied the standards. In 2012, 31 cross-provincial buffer sections including 41 sampling sections were monitored in Songliao basin. Songhua River basin includes 18 buffer sections and 27 sampling sections. The others are located in Liaohe basin. In 2013, 43 cross-provincial buffer sections including 73 sampling sections covering the whole basin were monitored. Among of them, 25 cross-provincial buffer sections (47 sampling sections) were located in Songhua River, while others all were located in Liaohe basin.

Key problems to be solved. (1) Establishing the water quality security and technical guarantee system for high risks trans-boundary river in cold area. It mainly includes: key technology development on water pollution accidents prevention and control, application of recycling industries and clean production technology, breakthrough of wastewater treatment technology in freezing period. (2) Establishing technical support system for aquatic ecological risk assessment. It mainly includes: exploring the impact of water pollution on river aquatic organism, Safety assessment system for river 
water quality, prevention and management system for sudden pollution accident risks. (3) Constructing the water quality monitoring and pollution warning system in cold areas. It mainly includes: establishing water quality prediction mathematical model for polluted river, optimization of monitoring point arrangement, implementing the monitored ability at different levels. (4) Improving the trans-boundary river management technology in cold heavy chemical industry area. It mainly includes: water quality standard in different countries, similarities and differences of water environment management system, establishing water environment management technology platform. Some suggestions. According to the present characteristics of trans-boundary water environment management in Songliao basin, some suggestions to strengthen the water environment management are proposed: (1) Basin management law. Promoting the water act and regulation system establishment, strengthening the coordination and development of basin and local water laws, and providing legal protections for basin hydraulic business development. (2) Basin management system. Explicating the responsibility of River basin Committees, and making it separated with local government to avoid local protectionism. (3) Basin authority system. Further strengthening the functions of basin authority, such as basin planning and management, unified management of flood defenses and water resources, and basin integrated law enforcement. (4) Mature management and economic methods. The market mechanism is applied to fully arouse the industries' initiative and raise money from social for basin management.(5) Strengthening environmental management. Continuing to strengthen total emission control measurements, and seriously enforcing laws and regulations; For industry wastewater prevention, first considering the whole production process control technology, promoting clean production, and recycling the industry wastewater. (6) Encouraging public participation mechanism to promote and improve the basin management works. Establishing the democratic management system for water resource, it means that establishing public and water users participation mechanism in the process of water planning, water rights initial allocation, water supply and water price adjustment. (7) Strengthening the scientific and technological support. Promoting the basin monitoring, information share and publishing system construction. Strengthening the practical technique development on basin resource utilization and environmental protection. Quickening the steps of technique promotion to satisfy the demand of modern basin comprehensive management.

\section{Acknowledgements}

This research was supported by National Natural Science Foundation of China (51308150), Specialized Research Fund for the Doctoral Program of Higher Education (20132302120072), China Postdoctoral Science Foundation funded project (2013M541396), Basic Research Operating expenses Program of Heilongjiang River Fisheries Research Institute.

\section{References}

[1] D. Phillips. Trans-boundary water co-operation as a tool for conflict prevention and broader benefit sharing. Eldis, 2006.

[2] Bai yiyan. Study on the mechanism of Songhua River basin management. Beijing University of Chemical Technology, 2006.

[3] Zhang jianyu, Qin hu. Difference and learning-comparing the water pollution prevention between China and America. Environmental Protection , 14(2007) 74-76.

[4] Tang tianzi. A comparative study of environmental management systems and policies between china and Japan. Contemporary Economy of Japan, 156 (2007) : 2-5

[5] Hu xiaojuan. Lessons from the treatment of Lake Biwa. Environment, 8 (2007) 34-35.

[6] Wang haiyan, Ge jiantuan, Xing he, Cai kuifang. European union trans-boundary river basin management and its reference value for the water environmental management in china. Resources and Environment in the Yangtze Basin, 17(2008): 944-947

[7] Chen Hui. Total catchment management in Australia. Environment Herald, 1(1997) 3-5. 